\title{
OPTIMALISASI LAHAN PEKARANGAN SEBAGAI UPAYA PENINGKATAN PENDAPATAN MASYARAKAT DI LINGKUNGAN PENGUBENGAN KAUH KELURAHAN KEROBOKAN KELOD KABUPATEN BADUNG
}

\author{
N.N.A. Mayadewi ${ }^{1}$, I.M. Sukewijaya ${ }^{2}$, I.N.G. Astawa $^{3}$, dan I.K.A. Wijaya ${ }^{4}$
}

\begin{abstract}
ABSTRAK
Sayuran adalah tanaman hortikultura, berumur kurang dari setahun, merupakan sumber mineral, vitamin, protein, dan serat. Guna memenuhi kebutuhan akan sayuran, salah satu jalan yang bisa ditempuh adalah dengan mengoptimalkan penggunaan lahan pekarangan untuk budidaya sayuran. Budidaya sayuran yang bisa dilakukan diantaranya dengan menggunakan polibag, pot, pemanfaatan barang bekas, maupun dengan cara vertikultur. Cara budidaya sayuran ini sangat penting diperkenalkan kepada masyarakat, khususnya ibu rumah tangga yang memiliki waktu lebih banyak di rumah, sehingga waktu yang tersisa setelah mengurus keluarga bisa diisi dengan hal-hal yang bermanfaat. Pelatihan budidaya tanaman sayuran kepada ibu-ibu PKK yang berada di Lingkungan Pengubengan Kauh, Kuta Utara, Badung sangat tepat dilakukan, karena wilayah ini merupakan daerah pariwisata dimana lahan merupakan faktor pembatas dalam budidaya tanaman. Budidaya sayuran di pekarangan ini bisa memenuhi kebutuhan anggota keluarga, bahkan bisa dijual sebagai tambahan pendapatan. Metode yang digunakan adalah metode ceramah dan praktik langsung. Tujuan dilaksanakannya kegiatan ini adalah untuk memotivasi dan meningkatkan ketrampilan ibu-ibu PKK dalam budidaya tanaman sayuran. Output dari pelatihan ini adalah keterampilan sederhana dan bangkitnya minat ibu-ibu PKK dalam pembudidayaan sayuran. Sebulan setelah pelatihan, ketika dipantau ternyata semakin banyak ibu-ibu PKK yang tertarik untuk membudidayakan sayuran di pekarangan.
\end{abstract}

Kata kunci : sayuran, budidaya, pekarangan

\begin{abstract}
Vegetables are horticultural plants, annuals, are a source of minerals, vitamins, protein, and fiber. To meet the needs for vegetables, a way that can be taken is to optimize the use of home yards for vegetable cultivation. Vegetable cultivation that can be done is by using polybags, pots, used items, as well as by verticulture. How to grow vegetables is very important to be introduced to the community, especially housewives who have more time at home, so that the time remaining after caring for the family can be filled with useful things. Vegetable cultivation training for PKK members in Pengubengan Kauh, North Kuta, Badung is very appropriate, because this area is a tourism area where land is a limiting factor in crop cultivation. Vegetable cultivation in the yard of this house can meet the needs of family members, it can even be an additional income. The method used was the lecture method and direct practice. The purpose of this activity is to motivate and improve the skills of PKK members in the cultivation of vegetable crops. The output of this training is simple skills and increased interest of PKK member in vegetable cultivation. A month after the training, when monitoring was conducted, it appeared that more PKK members were interested in cultivating vegetables in the yard.
\end{abstract}

Keywords: vegetables, cultivation, yard

\footnotetext{
${ }^{1}$ Program Studi Agroekoteknologi, Fakultas Pertanian, Universitas Udayana, arimayadewi@unud.ac.id

${ }^{2}$ Program Studi Agroekoteknologi, Fakultas Pertanian, Universitas Udayana, imsukewijaya@yahoo.com

3 Program Studi Agroekoteknologi, Fakultas Pertanian, Universitas Udayana,nyomangede.astawa@yahoo.com

${ }^{4}$ Program Studi Agroekoteknologi, Fakultas Pertanian,Universitas Udayana, ketut.arsawijaya@gmail.com
} 


\section{PENDAhUluan}

Lingkungan Pengubengan Kauh terletak di Kelurahan Kerobokan Kelod, Kuta Utara, Badung. Di Lingkungan Pengubengan Kauh ini ada satu organisasi wanita yaitu PKK yang beranggotakan sekitar 140 orang. Sebagian besar ibu-ibu ini bekerja di bidang non formal untuk membantu keuangan keluarga. Jenis pekerjaan yang mereka lakukan antara lain tukng bersih vila yang banyak dibangun di wilayah tersebut, pedagang, dan kerja di garmen yang ada di sekitar tempat tinggal mereka. Pekerjaan yang mereka lakukan kebanyakan paruh waktu, sehingga mereka masih memiliki banyak waktu luang. Guna memanfaatkan waktu terluang tersebut maka pembudidayaan sayuran merupakan salah satu usaha yang sangat bermanfaat. Budidaya sayuran yang dilakukan oleh ibu-ibu lingkungan Pengubengan Kauh guna memanfaatkan waktu luang, disatu sisi dapat memenuhi kebutuhan keluarga akan sayuran, di sisi lain kelebihan hasil yang diperoleh dapat menjadi tambahan penghasilan bagi keluarga.

Sebulan sekali, setiap hari Minggu pada minggu kedua kelompok PKK ini mengadakan arisan. Pada saat acara arisan tersebut biasanya diisi dengan diskusi tentang berbagai permasalahan yang ada di Lingkungan Pengubengan Kauh, acara-acara keagamaan yang harus diselesaikan bersamasama, dan kadang-kadang diisi dengan penyuluhan tentang kesehatan dan berbagai jenis keterampilan. Saat pelaksanaan arisan ini merupakan saat yang sangat tepat untuk memberikan keterampilan kepada ibu-ibu PKK tentang pembudidayaan sayuran di lahan pekarangan guna mengoptimalkan lahan yang ada agar mampu meningkatkan kesehatan dan kesejahteraan masyarakat.

Sayuran merupakan bahan pangan asal tumbuhan yang mengandung kadar air tinggi, dikonsumsi dalam keadaan segar atau diolah minimum (Setyoadji, 2016). Masyarakat biasanya memenuhi kebutuhan akan sayuran dengan cara membeli, padahal menanam dan merawat tanaman sayuran sangat mudah. Persoalan yang dialami biasanya adalah masalah lahan. Untuk mengatasi masalah lahan, maka menanam sayuran dapat dilakukan dengan menggunakan polybag, pot, bambu, talang air yang disusun (vertikultur), ataupun dengan memanfaatkan barang-barang bekas sebagai wadah tanaman (Pujiastuti, 2017; Liferdi dan Saparianto, 2016).

\section{METODE PELAKSANAAN}

Metode yang digunakan dalam pengabdian kepada masyarakat ini adalah dengan metode ceramah dan diskusi, yang diberikan oleh Dosen Fakultas Pertanian Universitas Udayana. Praktik budidaya tanaman sayuran dengan berbagai metode yang diberikan dalam ceramah. Praktik yang dilaksanakan mulai dari persiapan media, penyemaian, penanaman, pewawatan, hingga pemanenan.

Pelaksanaan pengabdian diawali dengan pemberian pemaparan tentang cara dan teknik budidaya berbagai tanaman sayuran. Setelah pemaparan dilanjutkan dengan praktek langsung dari cara mencampur media sampai penanaman. Selanjutnya hasil praktek dari ibu-ibu PKK dibawa pulang untuk dipelihara. Pemantauan tetap dilaksanakan sampai tanaman berumur 1 bulan setelah transplanting. Peserta aktif berkomunikasi dengan anggota pengabdi melalui media Whatsapp untuk menanyakan permasalahan yang dijumpai di lapangan.

\section{HASIL DAN PEMBAHASAN}

Kegiatan Pengabdian kepada Masyarakat yang dilaksanakan di Lingkungan Pengubengan Kauh, Kerobokan Kelod, Kuta Utara, Badung, diawali dengan penyiapan benih tanaman sayuran yang akan digunakan praktik penanaman oleh ibu-ibu PKK. Benih dibeli di toko penyedia alat-alat dan 
bahan pertanian, kemudian disemai di pot try sampai benih tumbuh dan siap untuk dipindahkan (transplanting). Proses penyiapan bibit tanaman sayuran bisa dilihat pada Gambar 1.
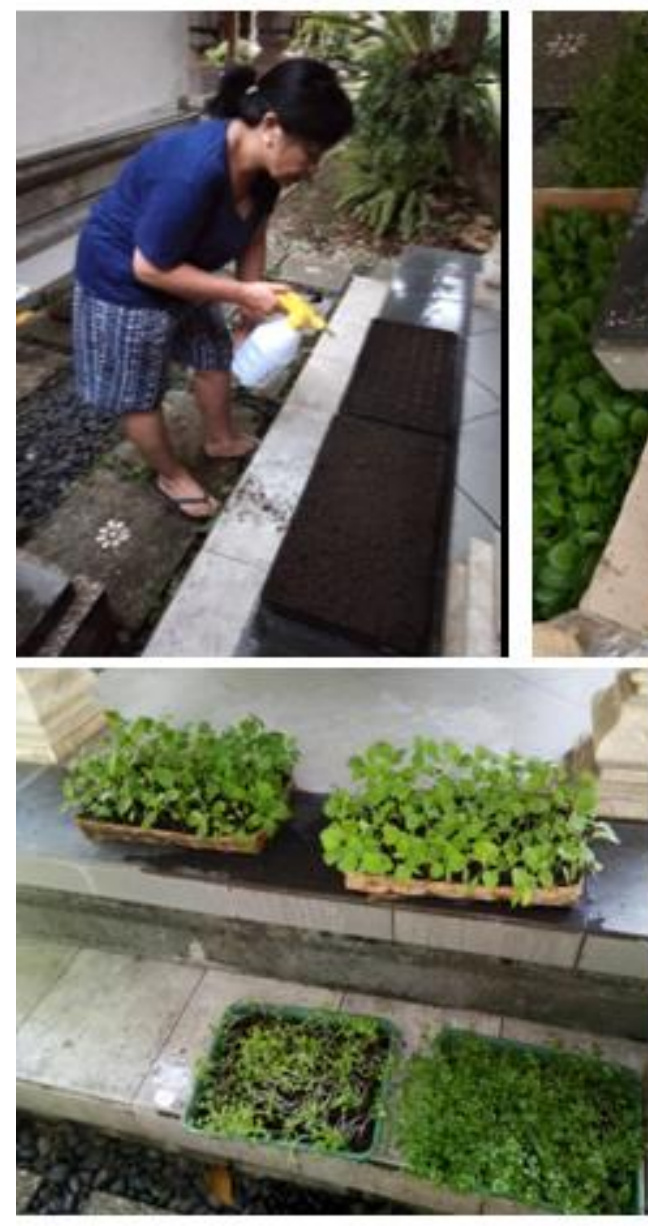

Gambar 1. Proses penyiapan bibit tanaman sayuran

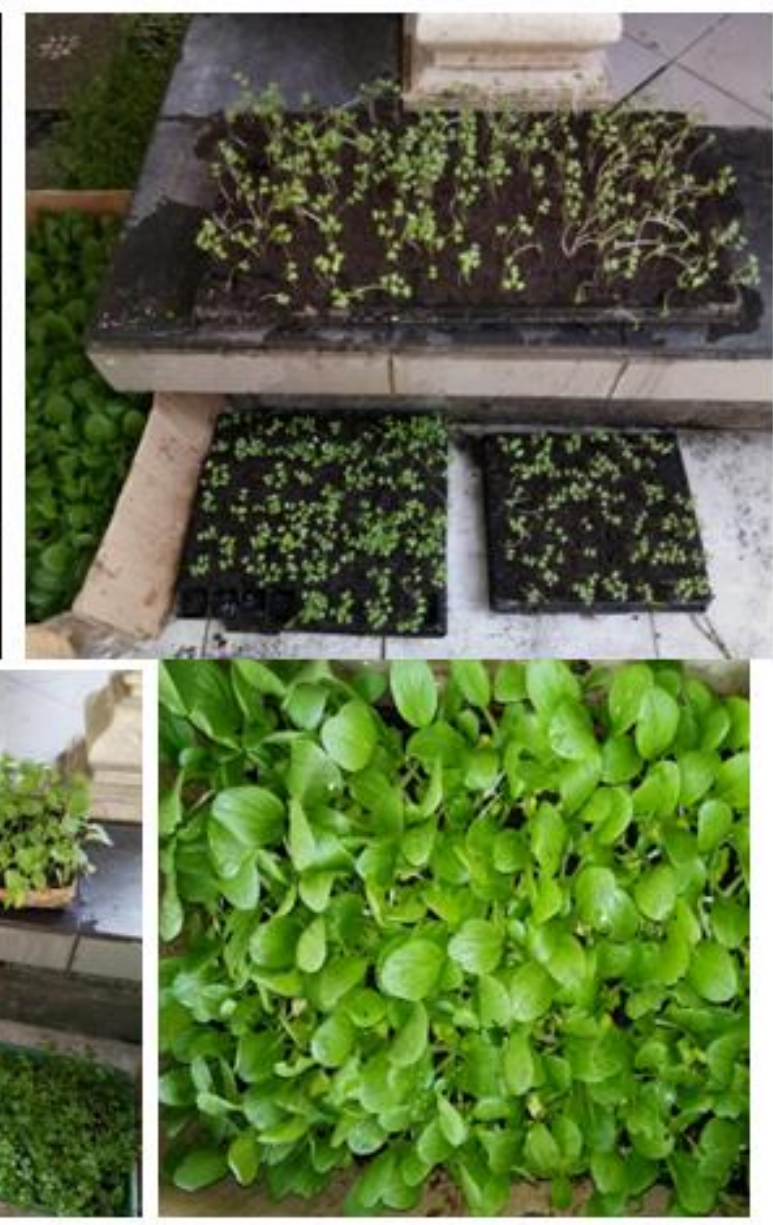




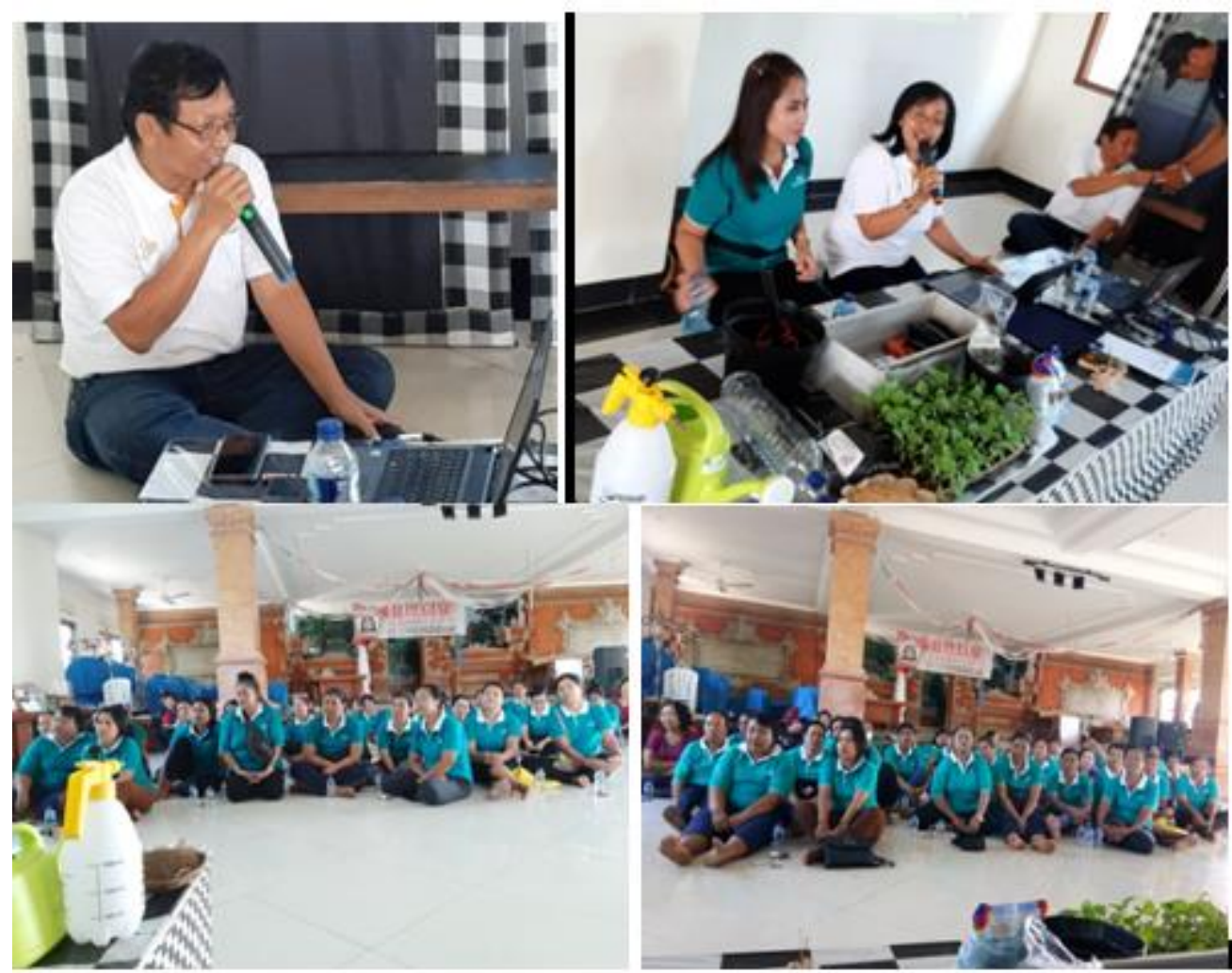

Gambar 2. Kegiatan ceramah atau pemaparan

Acara pokok dari pelatihan ini adalah praktik langsung penanaman tanaman sayuran dengan menggunakan wadah, mulai dari persiapan media tanam, penamanam, dan penyiraman. Wadah yang digunakan antara lain pot plastik, polibag, kemasan air mineral, talang bekas, dan rak kayu bekas.
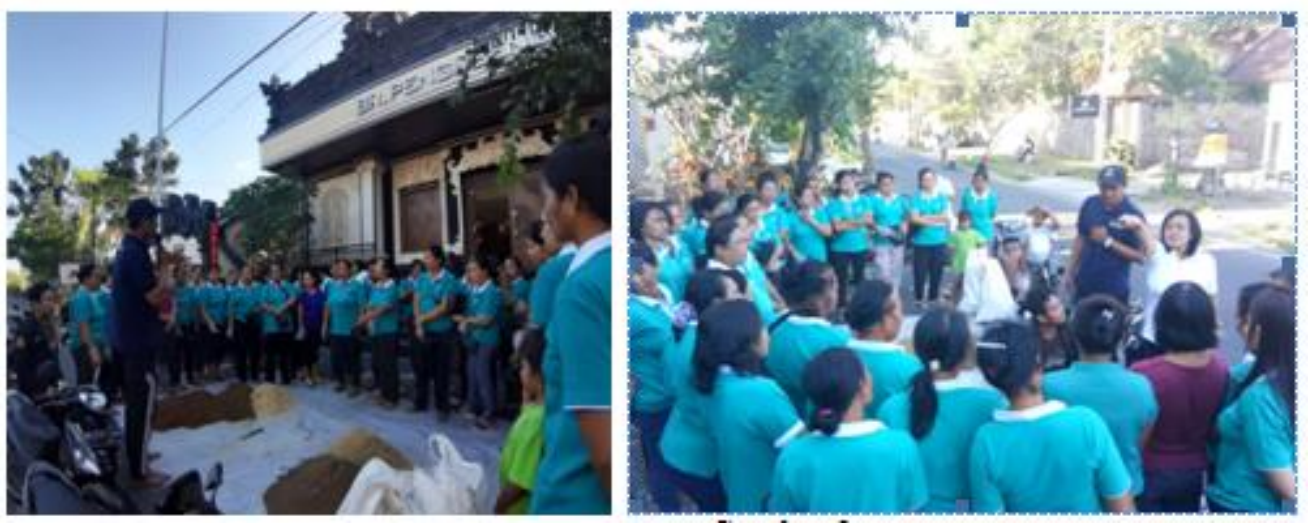

Gambar 3. Penjelasan di lapangan 

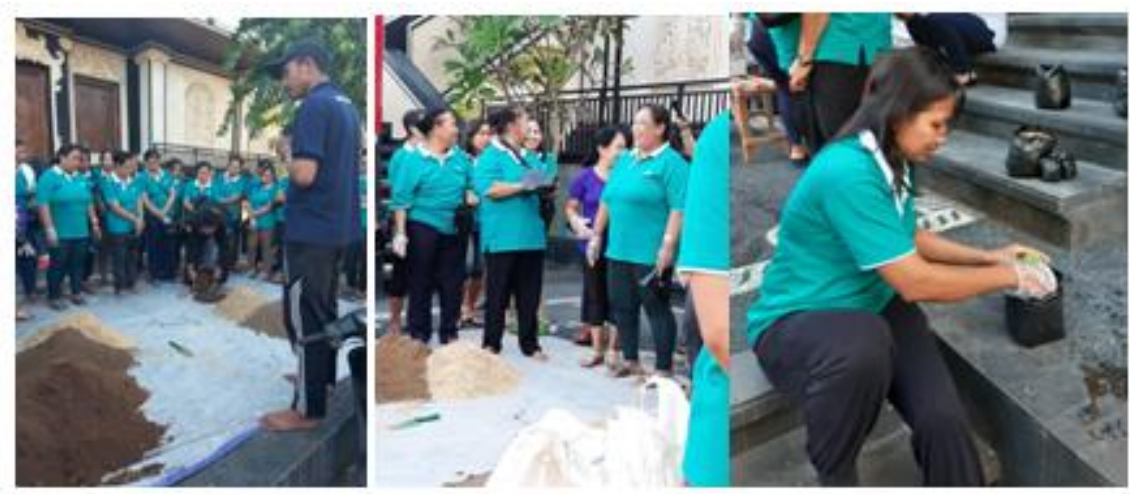

Gambar 4. Penyiapan media tanam dan praktik penanaman

Setelah pelatihan berakhir, komunikasi antara peserta dan Tim Pengabdian tetap berjalan melaui media sosial yaitu WhatsAap. Sering kali peserta pelatihan bertanya tentag cara perawatan tanaman sayuran yang telah mereka tanam. Sebagian anggota PKK juga mengirimkan foto tentang perkembangan tanaman sayuran yang dibudidayakan dan dipelihara di rumah masing-masing. Aneka tanaman sayuran yang berumur satu bulan setelah transplanting dapat dilihat pada Gambar 5.

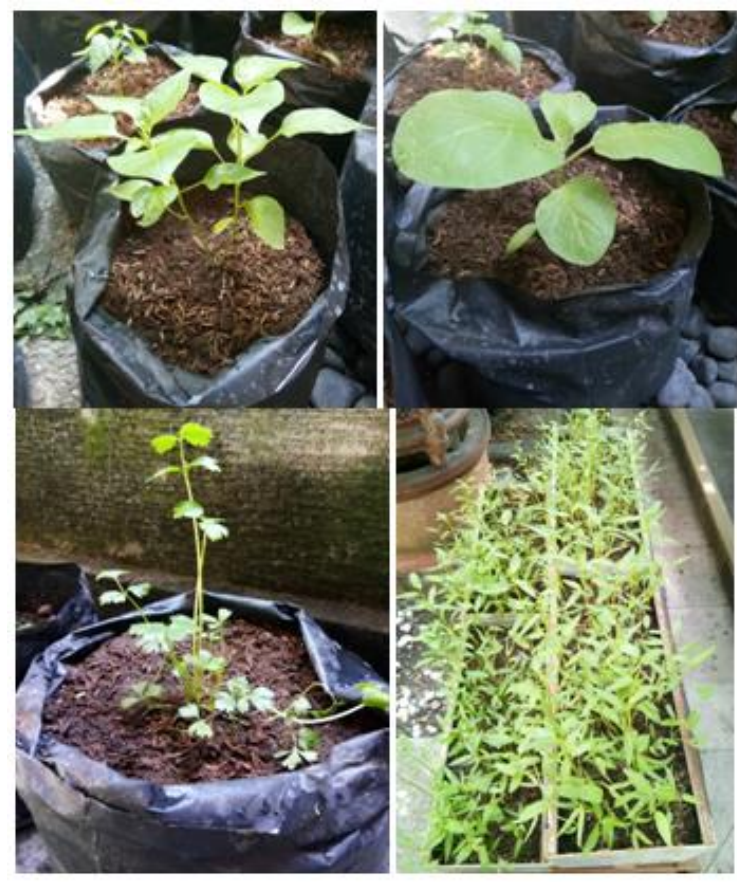

Gambar 5. Aneka tanaman sayuran umur satu bulan setelah transplanting

\section{KESIMPULAN}

1. Peserta sangat antusias mendengarkan dan menyimak ceramah dari tim pengabdian kepada masyarakat

2. Peserta mampu menyerap ilmu yang disampaikan, terbukti dari pantauan tim pengabdi setelah satu bulan pelatihan, tanaman sayuran mampu tumbuh dan berkembang dengan baik. 


\section{UCAPAN TERIMA KASIH}

Kegiatan ini didanai oleh DIPA PNBP Universitas Udayana Tahun Anggaran 2019 Sesuai dengan Surat Perjanjian Penugasan Pelaksanaan Hibah Pengabdian Kepada Masyarakat Udayana Mengabdi dan Hibah Udayana untuk Masyarakat Dana PNBP pada Lembaga Penelitian dan Pengabdian Kepada Masyarakat Universitas Udayana Nomor : 552-40/UN14.4.A/PM/2019, tanggal 10 April 2019

\section{DAFTAR PUStaka}

Liferdi, L., dan Saparinto, C. (2016). Vertikultur Tanaman Sayuran. Penerbit Penebar Swadaya. Jakarta. 108 hal.

Pujiastuti, E. (2017). 29 Teknik Urban Farming. Penerbit PT. Trubus Swadaya. Jakarta. 138 hal.

Setyoadji, D. (2016). Asyiknya Bertanaam SayuranPolybag \& Tabulampot, Cara Sederhana Menkmati Sayuran dan Buah Berkualitas. Penerbit Araska. Yogyakarta. 107 hal. 